УДК 291.11

Соловйов В. Г.

doi: 10.32620/gch.2019.1.09

\title{
РЕЛІГІЄЗНАВЧА ЕКСПЕРТИЗА НОВИХ РЕЛІГІЙНИХ РУХІВ: ОСНОВНІ РАКУРСИ ПРОБЛЕМИ
}

У статті розглянуто проблему релігієзнавчої експертизи нових релігійних рухів, яка має три рівні - онтологічний, гносеологічний і феноменологічний. Подано види релігієзнавчої експертизи, їх особливості й можливості.

Ключові слова: релігієзнавча експертиза, нові релігійні рухи, світська держава, церква, ідеологія.

The article deals with the problem of religious expertise of new religious movements which has three levels - ontological, epistemological and phenomenological. Types of religious expertise, their features and capabilities are presented.

Keywords: religious expertise, new religious movements, secular state, church, ideology.

В статье рассматривается проблема религиоведческой экспертизы новых религиозных движений, которая имеет три уровня - онтологический, гносеологический $u$ феноменологический. Представлены виды религиоведческой экспертизы, их особенности и возможности.

Ключевые слова: религиоведческая экспертиза, новые религиозные движения, светское государство, иерковь, идеология.

Поява нових релігійних рухів (НРР) кинула виклик сучасному суспільству, оголивши безліч проблем у різних площинах тих чи тих дисциплін. Держава, намагаючись убезпечити себе, створює механізми оцінювання загроз у релігійної сфери. Одним із таких механізмів прийнято вважати релігієзнавчу експертизу як превентивний захід у сфері стосунків релігії й держави. Однак проникнення юридичної термінології цієї процедури в релігієзнавство поставило питання про припустимість такого формального перенесення, про можливість неправильних припущень і спотворень у сприйнятті самих релігій. Узагалі, якщо придивитися до релігієзнавчої експертизи, то ми можемо помітити, що методично за цією процедурою стоять загальнонаукові завдання визначення, класифікації й оцінення будь-якого предмета дослідження. I сама проблема виникає, коли право, вторгаючись у галузь релігієзнавства, намагаючись формалізувати релігію, вихолощує пї зміст i несвідомо саме руйнує іiі розуміння.

Метою статті є спроба виявити й позначити основні рівні-ракурси релігієзнавчої експертизи НРР.

Тому, відповідно до стадій розвитку будь-якого поняття, на наш погляд, ця проблема має кілька рівнів розкриття. На своєму первісному рівні це необхідність виявити систему суперечностей, у яких опинилося сучасне релігієзнавство в спробі 
вийти 3 теоретичного рівня на практичний для оцінки сучасного релігійного життя.

Що ж змушує почати розглядати проблему розуміння НРР з аналізу самого релігієзнавства? Тільки те, що релігієзнавство за більше ніж століття свого існування почало втрачати смисли свого власного існування, втратило власну ідентичність. Дослідники почали ставити запитанням, чи існує воно взагалі? Аналізуючи різні публікації, присвячені стану сучасного релігієзнавства, можна виділити кілька напрямків (пошуку форм визначення) уявлення релігієзнавства.

Релігієзнавство як система наук. Розуміння релігієзнавства як «комплексної дисципліни» (формальної суми наук про релігію) призвело до питання статусу релігієзнавства (яке співвідношення різних дисциплін всередині релігієзнавства, проблеми базової дисципліни й статусу історії релігії), питань структури дисципліни, критеріїв приналежності до неї й т. д. Широке або вузьке визначення релігієзнавства (І. М. Яблоков) - присутність або відсутність філософії релігії, теології та інших наукових дисциплін - лише вказало на одну зі сторін цієї проблеми. У цьому розумінні дослідники зауважують, що релігієзнавство давно вже постає не більше як загальним позначенням сукупності конкретних напрямків наукового вивчення релігії (історії релігії, філософії релігії, психології релігії, соціології релігії). Саморозвиток релігієзнавчих дисциплін давно вже призвів до того, що вони існують радше на сторінках підручників, ніж у вигляді діючої системи знання. Розуміння релігієзнавства як «рамкового поняття» (І. П. Давидов) швидше за все вказує на комплекс дисциплін, а не комплексну дисципліну, оскільки релігієзнавство відокремлюється не за предметом, а за об'єктом дослідження, фіксуючи свою увагу на всьому, що так чи інакше пов'язане з релігією як глобальним соціокультурним феноменом. У релігієзнавства немає свого унікального методу, що відіграє роль маркера («Хто його застосовує, той релігієзнавець»). Якщо немає свого предмета й методу, руйнується вся будівля теоретизації. Така наука виявляється «фікцією без опори». Тому дослідники стверджують змістовну порожнечу релігієзнавства. У словосполученні «історія релігії» релігієзнавець, на відміну від історика, чує тільки друге слово. Тому логічне коло визначення сучасного релігієзнавства змушує відкинути предикат «науки» й перемкнути свою увагу на аналіз поняття «релігії».

Релігієзнавство як система проблем. Предметна плюралізація, необхідність відмови від іiї однобічності призвели до нової форми подання релігієзнавства як системи проблем: проблема дослідницької позиції релігієзнавця, проблема визначення релігії, проблема походження релігії, проблема класифікація релігій в сучасному релігієзнавстві та ін. Однак подібний підхід подання дисципліни призводить до ще більшої невизначеності розуміння релігієзнавства. Відсутність загальноприйнятого визначення й класифікації релігії (на сьогодні більше 750 визначень і 50 класифікацій) завела дослідників у глухий кут, черговий раз змусила засумніватися в методологічних можливостях дисципліни. Множинність тлумачень центрального поняття, народжених різними науками про релігію, призвела знову до логічного кола, указавши, що проблема в самих цих «науках».

Релігієзнавство як система систем. Метаметодологічні пошуки сучасного релігієзнавства виявили новий ракурс визначення дисципліни. Він так само дуже 
широко поданий у навчальній літературі, але своєю появою викликаний необхідністю відображати сучасні процеси, що відбуваються в суспільстві й державі, адекватно оцінювати НРР. Спочатку у зв'язку зі зміною законодавства про релігію постало питання про справжню кількість тих чи тих релігій. Кожна національна школа релігієзнавства почала видавати різну довідкову літературу (словники, енциклопедії, спеціальні збірники для різних державних органів), однак після питання про необхідність реєстрації релігій з'явився новий ракурс релігієзнавства - релігії й права. Більш за те, деякі дослідники стали ототожнювати релігієзнавство тільки 3 таким розумінням i будувати структуру дисципліни в подібному ключі («Судове Релігієзнавство» Тихонравова, «Крімінотеологія» Башкатова та ін.). Більш за те, з'явився інститут релігієзнавчої експертизи, який став нагадувати за всіх своїх заяв про об’єктивність і толерантність орган дізнання інквізиційного трибуналу, де від його рішень почала залежати доля тієї чи іншої релігії. Було випущено кілька цікавих видань, присвячених цій проблематиці, різними авторами (I. В. Загребіна, А. В. Пчелинцев, Е. С. Елбакян; А. К Погасий і ін.). 3 одного боку, право вказало нову синтетичну визначеність, де релігієзнавчій експертизі (праву) була підпорядкована вся система наук релігієзнавства, а питаннями ії були, власне, головні проблеми всього релігієзнавства. 3 другого боку, воно виявило всю ту штучність i нерозв'язаність питань, що стоять перед релігієзнавством. Тому можна погодитися 3 різними авторами, які стверджують, що для визначення сучасного релігієзнавства необхідно переглянути питання 3 філософії та методології науки й гуманітарного знання зокрема; вибудовувати нормативну епістемологію релігієзнавчого знання; виробити критерії можливих класифікацій у межах метатеорії релігієзнавства; звернутися до питань логіки.

I поки пошук нової релігієзнавчої парадигми не увінчався успіхом, на колишньому рівні зберігається відмежування окремих дисциплін між собою, а також відсутність єдності в релігієзнавчій спільності. Нерозв'язаність методологічних суперечок змушує дослідників формалізовано підходити до навчальної дисципліни, не вдаючись у проблеми, що виникли в релігієзнавстві, і відповідно більше відштовхувати від себе тих, хто вивчає цю дисципліну, ніж дійсно привертати увагу до необхідності пошуку відповідей, які стоять перед науковим товариством.

Історико-онтологічний ракурс. Це потреба розглянути основи - теоретичні проблеми сучасного релігієзнавства, історичного буття релігії і його форм правового втілення в державі. Результат такого аналізу дозволить уточнити поняття релігії, нового релігійного руху і його історичних форм як нової релігійної свідомості, нових релігійних груп i, власне, НРР.

Розглянемо тут один 3 початкових аспектів експертизи НРР. Традиційно в релігієзнавстві ми стикаємося 3 безліччю самоназв у релігіях, на які ми мало звертаємо уваги. Так, говорячи про буддизм і зустрічаючи назви «шлях Будди» (i «шлях Дхарми») або «іслам» (і «магометанство»), ми не відчуваємо подвійності сприйняття, що перед нами різні релігії. В історії ці релігії сформувалися як ціле, як поняття, зумовлені своїм особливим змістом. Тому, говорячи й описуючи історію релігій, ми використовуємо імена-терміни як поняття для подання релігійного життя. 
Практика конфесіоцентризму взагалі дуже часто призводить до назв за іменем засновника (християнство - від «Христос», зороастризм - від «Зороастр», конфуціанство - від «Конфуцій» і т. д.).

Поява НРР указала, що використання традицією самоназв релігій може завести в глухий кут будь-якого дослідника, оскільки за гарною вивіскою ми можемо зіштовхнутися 3 абсолютно порожнім змістом. I проблема тут не в тому, що асоціальна діяльність НРР призводить до множинності конфліктів у суспільстві й необхідності ухвалення до них будь-яких заходів правового характеру. Якраз виникнення НРР змушує переглянути безліч питань релігієзнавства, до цього моменту само собою зрозумілих, указує на проблеми як теоретичного (наприклад, проблема визначення релігіï), так i практичного (проблема класифікації, релігієзнавчої експертизи).

Коли ми говоримо про НРР, то забуваємо, що вони перш за все релігії, а потім тільки отримують свій атрибут «нові», забуваємо, що між «природними» й «позитивними» релігіями мінімум та різниця, що перші утворюють поняття релігії, а другі $є$ історичними формами розгортання цього поняття в кожному зі своїх моментів. У цьому розумінні НРР - це безліч конфліктів, які народжуються в історичному русі релігії як поняття за об'єктивації зазначених моментів між учасниками цього історичного процесу.

Так, розкриття моменту «релігійної свідомості» призводить до множинності значень, у яких реалізувалися глибинні прагнення різних поколінь людей, те загальне, що стало основою для реалізації світоглядної функції цих релігій. Це, своєю чергою, одночасно й боротьба цих смислів, яку ми бачимо від розвитку ранньої апологетики цих релігій (створення механізмів захисту, спростування, затвердження положень віровчення) до формування «догматичних критеріїв» відмінності тих від тих. Не дивне звідси прагнення багатьох дослідників, стаючи до класифікації релігії, говорити про них як про класифікацію різних віровчень, зокрема індуїзму, християнства, ісламу та ін. Усе було б добре, але поява НРР виявила суперечності в цьому підході, оскільки в них була присутня частина від кожної історичної релігії, а щось ще до цього й не зустрічається в історії віросповідань. Однак усе одно, зважаючи на цей абсурдний момент, у всіх публікаціях простежується одне й те саме: розглядати їх як різновид («нео-») історії релігії (неохристиянство, неосхідні релігії, неоязичництво й т. д.). Тому можна розглядати НРР як конфлікт смислів, предметом якого є як історичні релігії, так і сфера наукового знання, яка намагається їх описати.

Тому можна вважати: 1. Із формально-логічного погляду в низці класифікацій здійснено неправильний поділ - порушення єдиної підстави поділу, можливий перетин об'ємів видових груп тощо; 2. Подібні класифікації за змістом не закінчені: виникнення якогось найновішого різновиду релігії буде примушувати дослідника вводити або новий видовий клас, або зараховувати його до невідповідного (тобто межі визначені емпірично); 3. Поділ нерівномірний (послідовники Блаватської, Андрєєва - це не рухи з конкретними назвами; неохристиянські групи за переліком мають майже весь обсяг; немає неоісламських, неоіудейських груп тощо); 4. Побудовані класифікації незадовільні, оскільки за самоназвою руху може ховатися 
зовсім інший зміст.

Звідси запозичена термінологія історичних традицій формує нове конфліктне поле. Так, можна зустріти такі назви в НРР: «Церква сатани», «Церква Саєнтології», «Церква останнього заповіту» й т. д. Із другого боку, ми зустрічаємо назви, які мають «світські» позначення у вигляді асоціацій, товариств, клубів: «Міжнародний центр магії», «Суспільство Друїдів», «Центр Юнівер». Фахівці відзначають, що вживання тих чи тих позначень пов'язане 3 міркуваннями практичної вигоди: намагаються уникнути обмежень, що містяться в тих чи тих трактуваннях їхніх термінів. Наприклад, якщо НРР вважається релігією, то в багатьох державах це звільняє його від деяких податків, але, з другого боку, доступ до викладання в школі, виші для такої організації виявляється закритим. Головною проблемою, яка тут може бути виявлена, $\epsilon$ «розрив» між зовнішньою самоідентифікацією й внутрішнім змістом НРР. Причому слід зауважити, що аналіз таких рухів марно будувати на підставі їх писань (віросповідань), тому що такі «асоціації» не мають загальноприйнятого канону. Критичний огляд «езотеричної» літератури, наприклад творів Реріхів, із богословського погляду, проведений А. Кураєвим, викликав тільки роздратування 3 боку цієї асоціації, а також захист наукової громадськості.

Другий момент поняття релігії - це «релігійна самосвідомість». Це рух від суб'єктивного до зовнішнього світу, це процес опредметнення змісту віровчень. Це сфера реалізації психотерапевтичної або компенсаторної функції релігії. І знову поява НРР поставила під сумнів розуміння цього моменту, оскільки перенесла конфлікт у сферу внутрішнього життя вірян, конфлікту різних етичних систем. У сучасному світі наукове знання зіштовхнулося з безліччю підстав особистої поведінки, яка може суперечити сформованим і наявним нормам суспільства.

Найскладніший момент, на наш погляд, без якого жодна релігія не може вважати себе такою, це поняття «релігійна діяльність». Це та сфера, у якій перший і другий момент «знімають» себе, це момент набуття історичних форм релігії. Тільки в цьому моменті реалізується одна з головних функцій релігії - культурнотранслювальна - як форма ретрансляції, відтворення з покоління в покоління традицій суспільства. Звідси бажання багатьох дослідників у класифікації релігії спробувати виявити, наприклад, зв'язок між мовою, нацією й релігією або історичними культурами й релігією та ін. Основна схема, яка склалася у вітчизняному релігієзнавстві, це поділ на родоплемінні, національні та світові (наднаціональні). Але й тут поява НРР поставила цей підхід у глухий кут. Куди їх зарахувати - до первісних, національних, світових? Крім того, уся історія релігії - це одночасно історія різних держав, але разом із ним i різних правових систем. Сучасне релігійне життя - це конфліктне поле на державному рівні, де розгортають себе різні види: від примітивних правових традицій (мононорми) через різні національні правові системи до універсальних у межах одного цілого. Чи може вижити держава, яка містить у собі таку велику кількість суперечностей? Це питання, напевно, може бути розв'язане, коли, окрім горизонтальних відносин різних соціально-правових інститутів, виникне ієрархічна вертикаль принципів побудови й розвитку держави. Але для цього повинні виникнути нові моделі відносин, у тому числі й із релігією. Поки що спроба утримати в межах 
однієї держави представників різних культур призвела до кризи сучасну Західну Європу.

Проте це ще не все. Власне, що може розглядатися як аспект поняття НРР, це те, що розвиток історичних форм релігії, різних держав, права призвів до виникнення нового поняття «світська держава». Його особливість полягає в тому, що історичні релігії втратили можливість розвивати себе як релігії, що призвело навіть до питання про «кінець історії». Але ця видимість була лише оманою: релігійне життя не стоїть на місці, воно йде своїм неквапливим кроком. Як же це можливо? Держава самоусунулася від історичних релігій. Однак поява комунізму, фашизму продемонструвала, як боротьба різних релігійних ідеологій на підставі матеріалу «історичних традицій» може бути підгрунтям для пошуку нових або затвердження вже сформованих ідентичностей, бути підгрунтям для переділу світу. У цьому розумінні можна припустити, що НРР - це «релігії-містки», що пов'язують минуле й сьогодення традицій, це каталізатори процесів, що відбуваються в суспільстві, лакмусовий папірець, який може перетворитися на бич, якщо на них не буде звернено належної уваги.

Так, М. Епштейн у роботі «Нове сектантство» в літературному жанрі виявив проблеми НРР, причини їх появи. Описуючи нові види сект - «їжосвятцев», «кровосвятцев», «домовитян», «добровірів», «гріхівників» та ін. - як комедії ідей, він дуже тонко підмітив, що природа сект знаходить нову сферу. Це сфера ідентичності людини в пострелігійну епоху. Це нова сфера сенсів, яка за своїм змістом не може бути зведена до «традиційних релігій». За фрагментованістю життя сучасної людини й зведенні в ранг «абсолютного» якоїсь частковості ми бачимо прагнення до повернення глобальних смислів-ідентичностей, навколо яких розгортається нова історія. У тому ж розумінні відома книга Ю. Канигіна «Шлях аріїв» сакралізує місце української нації в минулому й майбутньому історії людства за допомогою фальсифікації безлічі імен і подій. Також вона одночасно може служити наочним прикладом прояви нової релігійної свідомості в Україні, яка, експлуатуючи ідею національності, відроджує релігію в межах «світської держави».

Гносеологічно-методологічний ракурс. Сьогодні прийнято розглядати проблему НРР і ролі й оцінки їхньої діяльності через призму дихотомії методологій церкви й науки, але, на наш погляд, проблема набагато глибша й пов'язана в сучасності з існуванням поняття «світська держава». Експертиза в справах релігії в історії виникає, коли відбувається видозміна моделей стосунків між церквою й державою, на підставі чого виділилися різні ідеології, які надалі почали впливати як підгрунтя різних методологій для оцінки НРР. До речі, власне сплески появи НРР у тій чи іншій державі пов'язані саме зі змінами в законодавстві у сфері релігії. Тому можна сміливо стверджувати, що, з одного боку, сутність НРР ховається в питаннях стосунків між церквою й державою, а не в часі їх появи: недарма існують дослідження, які розглядають НРР як «рух-містки». Із другого боку, необхідність в експертизі НРР виникає, коли до цієї дихотомічної системи під’єднуються різні гносеологічні концепції, які намагаються зняти цю суперечність. Звернемо увагу, що сучасне частковонаукове релігієзнавство або навіть сучасне православне 
сектознавство стають подібними, прагнучи до єдиної форми наукового знання. Це намагання розгортає цілі баталії за відповідність цим стандартам, навіть не замислюючись, з чим пов'язана така потреба. Це відображає кризу сучасного ліберального світопорядку, указуючи, що проблема вже не методологічного характеру. Сучасне виникнення стосунків держави й релігії на підставі соціального партнерства говорить про назрілий новий етап цього діалогу, пошуку нових моделей взаємин.

Тому не можна вже так просто протиставити методології релігієзнавства й сектознавства в оцінці НРР і піддати ту чи ту критиці за їхню невідповідність: вони починають поставати як один із можливих методів розуміння й оцінки НРР, що «грають на одному полі» наукового знання, іноді навіть присутні в одному «таборі», як, наприклад, у разі антикультового руху. Проблема, на наш погляд, в іншому: разом із колосальними історичними зрушеннями, які призвели до зміни в сутності взаємодії релігії й держави, відбулися не менш значні зміни в співвідношенні буття й знання, із якого виділилися всі сучасні ідеології, які врешті-решт і $є$ головною ключовою точкою для пояснення видів релігієзнавчої експертизи НРР. За всіма «лівими»«правими» можна виділити дихотомії методологічних позицій, але вже ідеологій. I якщо ми вже відходитимемо від критики оцінки видів релігієзнавчої експертизи НРР, то перейдемо до критики ідеологій, які послідовно розгортають себе в різних державах і які, власне, i стоять за сучасними проблемами в релігійній сфері. Розглянемо основні методології, на яких «виросли» види сучасних експертиз НРР:

1. Частковорелігіознавчий об’єктивізм $i$ антикультизм. Частнонаукове релігієзнавство проголосило необхідний новий критерій - «об’єктивізм» - для дослідження НРP i критерії науковості як основоположні (верифікації, раціональності, методичності, системності т ін.), для того щоб уникнути історично сформованих суб'єктивних забобонів, оцінок і думок у суспільстві, але насправді загнало себе в ще більшу суб'єктивність. Прагнучи до незалежної єдиної оцінки НРР, підхід породив безліч дисциплін у релігієзнавстві, висновки кожної з яких можуть суперечити один одному: софістично або довести, або спростувати будь-які оцінки НРР залежно від необхідного контексту обвинувача чи захисника.

Перша школа широко подана в пострадянських роботах О.Г. Балагушкіна, А. Баркер, П.С. Гуревича, І. Кантерова, В.Ф. Миловидова, Л.Н. Мітрохіна, Б.3. Фалікова та ін. Вона побудована на необхідності виявлення за релігійними феноменами їх об'єктивних антропологічних і соціальних функцій, виведених із підстав тієї науки, до якої належить дослідник, - соціологічної, філософської, психологічної, історичної та ін. Релігієзнавець тут перш за все скептик, який стверджує можливість множинного тлумачення дійсності за безумовного визнання тільки за наукою права на справжне «пояснення». Однак сформований «конфесіоцентризм» i нормативізм, статичність у розумінні нової релігійності поставили під сумнів можливість об'єктивного аналізу названого феномена за цим підходом. Друга - антикультова - школа (від англ. anti-cult), ставить головним своїм завданням боротьбу з НРР і нівелювання їхнього впливу на навколишнє суспільство. Основним способом боротьби є створення негативного іміджу НРР у суспільстві за 
допомогою виявлення негативної інформації про їхні методи й форми роботи зі своїми послідовниками, розкриття матеріалів, які так чи інакше їх компрометують. Роботи антикультової школи, відрізняючись описовим характером, спрямовані переважно на розкриття реально або потенційно деструктивних складових НРР. При цьому спектр дій може варіюватися від чіткого й обгрунтованого викладу й захисту своїх позицій у судовому порядку аж до організованого масового пікетування й зриву різних заходів НРР.

Які ж тут постали методологічні проблеми під час аналізу НРP у першому підході? По-перше, проблематичність осягнення феномена релігії. За європоцентричною (конфесіоцентричною) моделлю розкрилося відразу кілька моментів: 1) дослідник зіштовхується 3 проблемою знаходження специфічного «релігійного елементу», який дозволяє об'єктивно, на загальновагомому, «інтерсуб'єктивному рівні» кваліфікувати ці феномени як «релігійні»; 2) недоліки сформованої традиції використання «запозичених» термінів; 3) необхідність удосконалення категоріально-понятійного апарату релігієзнавства. По-друге, відсутність чинного визначення НРР. По-третє, труднощі класифікації (як традиційних релігій, так і НРР), поява взагалі безглуздих класифікацій за самоназвою груп (неохристиянські, неосхідні, синтетичні й т. д.), які не наводять ніякої науково необхідної інформації, що передбачає ця процедура. Тому складність і багатоаспектність проблеми релігієзнавчої експертизи в цьому підході змушує дослідників повертатися до більш звичних і буденних категорій слововживання, що пов'язує поняття релігії перш за все з європейською культурою, із християнством, яке протиставляється всім іншим формам релігій. Неможливість створення загальновизнаного родо-видового наукового визначення релігії, коректного в формально-логічному аспекті, призводить у юридичній практиці до затвердження локально-оказіонального підходу, прямо ототожнює загальне поняття релігії 3 домінантними емпіричними соціальними об’єднаннями або «традиційними релігіями», оцінюючи НРР через їх призму.

2. Догматичний $і$ деструктивний конфесійний нормативізм зріс у сучасності в межах різних конфесій як спроба доповнити й дати оцінку НРР на підставі власного богослов'я. Тут прийнято розглядати в православній церкві три школи, де основною методологією постає спроба відродити й розвинути науку «сектознавство», створення базових підручників із дисципліни [1]. Крім того, слід зауважити, що історично богослов'я складається під впливом полеміки 3 єресями. Тому існування сучасних НРP - це необхідний етап для існування самих традиційних релігій, у них оживає методологічне минуле традицій.

Відродженню історичного сектознавства присвячує себе тут перша школа, що відповідно до відродження традиційного найменування НРР як єресі й секти пропонує «святоотцівський підхід» як єдиний «критерій» і «джерело» богослов'я й будує класифікації на підставі історичного поділу всіх сект на раціоналістичні й містичні. Друга школа спробувала розробити й упровадити в суспільну практику терміни «тоталітарна секта», «деструктивний культ» («Деструктивність або тоталітарність сект визначається не їх віруваннями, а їх методами діяльності»), 
методологічно спираючись на досягнення антикультової школи. Її представники головну небезпеку нових сект убачають не в антицерковних ученнях, а в їх соціальних доктринах і порушеннях ними прав людини. Головний акцент у полеміці 3 богословських аргументів перекладено на психологічні й навіть медичні, де передбачено, що ці групи «промили мозок» своїм адептам і порушують їхні права. Відповідно школа просуває вже сформовану класифікацію: поділ на неохристиянські, неосхідні та ін. Третя школа, називаючи себе помірним протикультом, пропонує взагалі «сектознавство» як універсальну методологію 3 дослідження НРР, намагаючись увібрати всі досягнення як історичного (традиційного), так і сучасного (деструктивного). Вона термінологічно спирається на поняття «нові релігійні рухи», «нетрадиційні релігії», стверджує, що час термінологічних суперечок уже минув i необхідно використовувати кращі із західних досліджень для сектознавства.

Коли ж ми переходимо до аналізу практичного застосування «сектознавства»від наївних до дуже складних методологічно, - то бачимо, що за всім цим корпусом простежується ідея введення поняття «норми» до НРР на підставі власної традиції. Саме такий спосіб розв'язання питання заклав до свого посібника для православних місіонерів із порівняльного богослов'я та сектознавства начальник інформаційноаналітичного центру місіонерського відділу синодальних установ Руської Православної Церкви (Московського Патріархату) кандидат юридичних наук А. І. Хвиля-Оліентер [9]. Для цього за вихідну релігію він вибирає православ'я (прийняті догмати церкви й особливості їі існування). Вибравши такий вихідний критерій, автор далі пропонує будувати класифікаційні таблиці: наскільки відрізняється будь-яка інша релігія від православ'я й за отриманням кількості балів i оцінювати ступінь деструктивності або творення релігійного руху.

3. Правовий абсолютизм $і$ нісілізм як спроба зняти суперечності першого й другого підходів. Необхідність зв'язку між предметом і методом змушує дослідників перемістити проблему у сферу права, розглянувши право як загальне, яке регулює різноманіття особливого. Проте тут знову постає проблема: право як метаправо не може бути загальним щодо релігії, воно народжується в релігії, із нею співіснує як єдине ціле, а потім разом із розвитком держав, відділяючись в окрему сферу, розвивається й знаходить самостійне буття. Коли ж право намагається зіставити себе з релігією, то воно забуває, що різні правові норми вже присутні як у традиційних, так i в НРР, i, створюючи закони про релігію, воно конфліктує із самими цими релігіями.

Між правом і релігією існують давні історичні зв'язки, які були предметом аналізу багатьох дослідників - як дореволюційних, так і сучасних. На необхідність пошуку таких зв'язків і навіть створення нових дисциплін указують безліч сучасних авторів. На їхню думку, новий ракурс проблеми може зняти соціальну напруженість у суспільстві НРР на підставі розроблення й упровадження нового законодавства, яке регулюватиме релігійне життя в державі [2]. Однак насправді, бажаючи вийти за межі свавілля множинності й «об'єктивності» частковонаукового релігієзнавства й нормативізму сектознавства, створюють ще більше свавілля й нормативізму.

Наприклад, у роботах А.В. Тонконогова [4], О.В. Старкова й Л.Д. Башкатова [5] ставиться складне завдання: у першій - комплексне соціально-філософське 
дослідження сектантства й навіть відродження світського варіанта науки сектознавства; у другій - дослідження зв'язків між правом і релігією та створення науки кримінотеології (кримінорелігієзнавство, на думку авторів, «неспівзвучне»). Однак далі заявленого вони не просунулися й, не зумівши провести понятійний зв'язок між релігією і правом, повністю занурилися в різноманіття особливого. Усю систему уявлень про релігію розглянули тільки через призму злочинів у ній, звівши до простої кримінальної статистики. Такий підхід може виявляти тільки один із боків релігії, але ніяк не явище в цілому. Це дорівнює загнанню уявлення про релігію в «прокрустове ложе» права для розв'язання часткових завдань, що стоять перед дослідниками.

Тому, швидше за все, демократична правова держава повинна будуватися на принципах самообмеження владних функцій у регламентації духовно-морального життя суспільства, свідомо допускаючи ризик «неправильного» світогляду як меншого зла порівняно з примусовим «правильним». У цьому контексті обмеження 3 метою профілактики протиправної діяльності у сфері свободи совісті здатні завдати незрівнянно більших збитків громадянському суспільству, ніж самі передбачувані порушення. Тим більше, що порушення в основному завжди виходили й виходять від влади, яка «зрослася» $з$ бюрократією панівної релігії. Спеціальні (по суті, неправові) обмеження діяльності світоглядних організацій (найважливіших інститутів громадянського суспільства) є важливим кроком до перетворення держави в одну велику тоталітарну «секту». Звідси жертвами можуть стати безліч «інаковіруючих» і «інакомислячих».

Як вважають деякі дослідники, віросповідання саме по собі навряд чи має значення в кримінальній статистиці. Суспільство реєструє лише приналежність до тієї чи іншої з наявних релігій, а не дійсний вплив релігійних догматів на думки й учинки. Якщо ми звернемося до даних статистики, то побачимо, що в суперечці про релігії посилаються на рід і число злочинів для доказу їхніх відносних переваг і недоліків. Облік поширеності тієї чи іншої релігії серед злочинців навряд чи може використовуватися для оцінки самої цієї релігії. Однак слід зазначити, що, як i показують дослідження, серед злочинців дійсно чимало людей релігійних.

Особливості негативного фону сучасних досліджень і призводять до правового нігілізму. Методологічні настанови, зміст, висновки й практичні рекомендації грубо суперечать принципам, що становлять підгрунтя конституційного ладу: світськості держави й рівності релігійних об'єднань. Звідси випливає: 1) ніколи законодавча система, що виникла й безпосередньо пов'язана 3 «традиційними» релігіями», у межах яких вона формувалася, не зможе адекватно оцінювати нові (що перебувають у стадії становлення й наявні) релігійні організації. Власне факт існування НРР робить їх можливим об'єктом «полювання на відьом» на законодавчому рівні для традицій під час упровадження й використання подібної системи, а тим самим порушує проголошувані права на свободу совісті; 2) Поклавши в підгрунтя «системи кримінотеології» ідею релігієзнавчої експертизи, автори «знищили» в дослідженні будь-яке уявлення про релігію, залишивши лише як предикат рудимент введеного концепту поняття «злочин». Звідси вони перенесли всю сформовану правову 
традицію на релігійну сферу та, хоча й надали можливість правового оцінювання злочинної діяльності тієї чи іншої релігії, фактично ж створили «поліцейську палицю» для контролю над нею.

Негативний досвід застосування релігієзнавчої експертизи за різних підходів може викликати бажання відмовитися від неї або створити прецедент, як у разі правового нігілізму, нівелювати ऑiі необхідність аж до повного посилення законодавства з релігії. Однак відмовитися від неї у «світській державі» не можна. Тут можна нагадати слова Ю.В. Тихонравова, у яких, на наш погляд, на переконливому прикладі стверджується аксіоматична необхідність релігієзнавчої експертизи: «Якби релігієзнавча експертиза була введена до Другої світової війни, то для того щоб визначити небезпеку нацистського вчення й заборонити його в межах ліберальної демократії, не потрібно було б переживати цей страшний історичний урок» [7, с. 241-242]. Тому, щоб вирішити проблему, на думку С.В. Качурової, треба вийти із системи «традиційні церкви - світська держава - нові релігійні рухи» й перейти до нової гносеологічної (онтичної) форми іiі існування [4, с. 77-78], до виникнення нової метаметодології, що знімає однобічності лібералізму й традиціоналізму (об’єктивізму, нормативізму й правового абсолютизму), загальної щодо наявних. Проте за такої абсолютизації можна побачити народження «гносеологічної релігії», зміну моделі стосунків релігією й державою, зникнення «світської держави» і, можливо, необхідності релігієзнавчої експертизи як наслідку ліквідації ідеологічного розриву - причини її появи.

Феноменологічний ракурс. Таким чином, можна стверджувати, що на сьогодні розгортаються три модуси - форми експертизи НРР. Історичний час поняття «світської держави» добігає кінця, і держава, в умовах поліконфесійності, шукає нові форми взаємодії з релігією. Виходячи 3 того, що експертиза як поняття своїм корінням сягає в систему права, а релігія в умовах «світської держави» шукає нове історичне втілення в його межах, виникають сучасні концепції «соціального партнерства», у яких союзи між державою (iі соціальними формами) і різними релігійними організаціями реалізуються в нових формах співпраці, що призводить до контролю в релігійній сфері.

Перший модус будується на безпосередньому ототожненні держави 3 однією 3 історичних традицій. Прагнучи до відродження духовності населення, держава намагається відродити одну 3 релігій, якій віддає перевагу, але тим самим i намагається оживити «старі» стосунки й проблеми, що йдуть шлейфом разом із цією традицією з історії.

Так, у Росії натепер досить активно поширена практика укладання угод про співпрацю між релігійними організаціями й окремими виконавчими органами державної влади, для чого було вироблено проект спеціального правового механізму взаємодії - соціальне партнерство [5, с. 131]. Під соціальним партнерством у контексті пропонованого законопроекту розуміють систему взаємодії органів державної влади й органів місцевого самоврядування 3 релігійними організаціями, спрямовану на забезпечення реалізації релігійними організаціями статутних цілей $\mathrm{i}$ завдань у вирішенні соціально значущих проблем. 
У цьому контексті принцип рівності релігійних об’єднань перед законом не передбачає побудови відносин держави з усіма релігійними об'єднаннями як із рівнозначними. Тому, за аналогією з конституційним принципом рівності громадян перед законом, який не виключає надання певним категоріям населення різних пільг, рівність релігії перед законом не виключає законодавчого закріплення диференційованого підходу до релігійних об'єднань і надання переваг деяким релігійним організаціям, виходячи $з$ їх історичного значення, особливої соціальної ролі, внеску в культурне життя.

Аналіз цього законопроекту викликав багато питань у експертів. Чи не слід розглядати його як спробу запровадження поняття «традиційної релігії» й прихованої протидії всім іншим? Перераховані в преамбулі релігії не відображають усього спектру конфесій, і не всі перераховані релігії зіграли дійсно «особливу» роль в історії держави або, навпаки, можуть бути не згаданими. Не має сенсу докладно перераховувати ті чи ті напрямки буддизму, ісламу, свідомо замовчуючи напрямки, що викликають суперечки навколо них. Автори виходять за межі правового поля, коли відмовляються називати «творчими» інші християнські церкви - католицьку, лютеранську, кальвіністську, методистську, Армію спасіння й т. д. Механізм акредитації нагадує механізм реєстрації й перереєстрації (потребує експертизи), що важко здійснити для деяких релігійних організацій. За бажання у вченні будь-якої релігії можна знайти що-небудь, що підходить під рубрику «спрямоване проти основ конституційного ладу». Не зовсім ясно, хто буде проводити експертизу доктрин різних релігій із метою встановити, що їх віровчення дійсно не містить нічого 3 перерахованого в проекті закону. Через розмитості критеріїв статусу соціального партнерства виникає небезпека свавілля з боку чиновників. Сама класифікація релігій на «визнані» i «невизнані» містить істотний дискримінаційний елемент, оскільки передбачає преференції держави щодо певних релігій, у той час як надходження до бюджету забезпечують усі платники податків і т. д. [5, с. 191-205].

Крім того, результатом такого ставлення може бути «бюрократична деформація», яка призводить до фактичного злиття обох інститутів. Моделі панування-підпорядкування притаманне придушення (підпорядкування) інтересів одного інституту іншим. У межах цієї моделі відносини держави й релігійних організацій можуть перерости у відкритий конфлікт. Слід зауважити, що теоретичні моделі державно-церковних відносин знаходять своє практичне застосування в контексті окремо взятої політичної характеристики держави - політичного режиму, що становить сукупність методів, засобів і способів здійснення державної влади. Оскільки політичний режим безпосередньо впливає на статус релігійної організації в державі, то він буде впливати на відносини, що виникають у політико-управлінській та ідеологічній сферах суспільного життя між державою й конфесією, тобто на державно-конфесійні відносини. Таким чином, політичне «просочує» сферу соціального, регулюючи, відтворюючи необхідні політиці відносини через право, мораль, традиції, культуру, релігію.

Як зауважує Ю. В. Тихонравов, боротьбу держави з небезпечними ідеологіями часто бачать під прапором збереження «традиційної релігії» або ж повернення до неї. 
Однак, по суті, коли держава починає розбирати й міркувати, яка релігія повинна бути збережена, вона майже завжди говорить про поліцейську релігію, тобто про таку релігію, яка могла бути максимально корисною для здійснення власних цілей держави. I заради цього держава готова під виглядом покровительства застосувати будь-яке насильство до «традиційної релігії», щоб привести іiі у відповідність зі своїми уявленнями. Тому можна говорити, що держава, яка бажає сприяти будь-якої релігії, не менше, а то й більше, небезпечна для цієї релігії, ніж держава, яка організує гоніння проти неї [7, с. 61-62].

Другий модус полягає в тому, що виникнення експертного руху й експертної ради для проведення державної релігієзнавчої експертизи є рефлексивною формою окремих видів релігієзнавства, це прояв світських ідеологій, які за ними стоять, це «око государеве» сучасності.

В історії подібний інститут вже існував і був пов'язаний із духовною цензурою. Суд Церкви про псевдовчення й нагляд над виданням і поширенням книг називався в широкому розумінні духовної цензурою. Вона полягала в засудженні творів, які проповідували псевдовчення, i в забороні православним читати їх. Спочатку державна влада після засудження єресі видавала розпорядження про спалення творів єретиків. Надалі ж твори не спалювалися, а відбиралися до патріаршої бібліотеки. Новий спосіб вилучення єретичних книг мав ту перевагу, що в разі потреби можна було за збереженими книгами ретельніше вивчити характер єресі, щоб успішніше протидіяти їй. У синодальну епоху вищою установою духовної цензури був Святий Синод; йому була підпорядкована вся цензурна служба. Духовній цензурі піддавалися не тільки призначені для друку твори духовного змісту, а й світські книги й статті, якщо світські цензори знаходили в них місця духовного змісту, що належать до догматів віри або Святого Письма. Тому з огляду на обсяг видаваної літератури була створена величезна структура зі своїми витратами для всебічного контролю, яка не змогла довго проіснувати. Ця структура зіткнулася $з$ тими проблемами, що й сучасне співтовариство експертів. Будучи штучним утворенням, воно вимагало фінансування, а відсутність єдиної методологічної бази для аналізу релігійних процесів суспільства викликало шквал критики й звинувачення в суб'єктивізмі. Сьогоднішні російські дослідники, аналізуючи релігієзнавчу експертизу як практичний інструмент судової системи, оцінюють їй однозначно негативно.

Особливість таких комісій, комітетів і т. д. у тому, що вони функціонують не самостійно, а є новою формою ідеологічної машини світської держави. За допомогою них держава може чинити прихований вплив на ті чи інші процеси, що відбуваються в суспільстві, особливо у сфері релігії, але не тільки всередині, а й зовні, тобто за кордоном. При цьому дійсні мотиви, які стоять за цим, можуть бути відразу не помітні, а проявлятися тільки згодом.

До цього ж модусу можна зарахувати й державу радянського періоду, яка за допомогою ради в справах релігії й комуністичної ідеології (релігійної за формою) продовжила ту ж діяльність щодо релігійної сфери, створивши чергові точки напруги в суспільстві. Як відзначають дослідники, радянська дослідницька традиція не 3'явилася на порожньому місці, а є «діалектичним» продовженням дореволюційної 
«сектознавчої» традиції. Це негативне ставлення виражалося в специфічній ідеологічній і політичній позиції щодо НРР. Формально, з одного боку, рада в справах релігії була органом при уряді СРСР і здійснювала партійні настанови в галузі державно-церковних відносин, із другого боку, перебувала в тісному зв'язку з КДБ СРСР і виконувала низку завдань, що не входили в ії функції: контроль за підбором кадрів релігійного об'єднання, нагляд за діяльністю духовних навчальних закладів, проходженням богослужінь, що було прямим порушенням принципу відділення церкви від держави, поступового витіснення релігії $з$ життя суспільства із заміною на власну ідеологію.

Третій модус полягає в тому, що сьогодні актуально звертатися до питання національної церкви України. Велика кількість дослідників звертають увагу, що розвиток української державності неможливий без розвитку української національної церкви. Ні політичні, ні економічні, ні духовні або культурологічні питання не можна розв'язати без іiі участі [3, с. 687]. Однак розв'язати їх неможливо без розуміння поняття «національної церкви», проблеми об'єднання українських церков та ін. Поява в українській науці інтересу до виявлення можливих форм взаємин держави й релігійних організацій і пропонованих можливих моделей взаємодії на підставі концепції соціального партнерства оживила дискусії навколо цього питання.

Однак, міркуючи таким чином, можна помітити, що ми виходимо 3 методологічного принципу розуміння релігії як набору функцій - світоглядної, психотерапевтичної, культурнотранслювальної та ін. I саме в такому ракурсі ми намагаємося зрозуміти історичні процеси, які відбувалися під час поширення світових релігій. Розуміючи історію як свідомість, спрямовану в минуле, ми звертаємо увагу, що всі світові релігії у своєму поширенні зіштовхнулися з етапом їх вибору. I буддизм, і християнство, й іслам в цьому розумінні були «обрані» так, як і зараз багато дослідників міркують, яка релігія чи комплекс релігій були б кращими.

Однак у чому небезпека такого міркування? Розглядаючи релігію тільки як функцію процесів, що відбуваються в суспільстві, ми забуваємо, що кожна 3 них формувалася в контексті своїх історичних умов й незалежно від часу несе на собі їхній відбиток. Тобто неможливо, наприклад, розв'язати питання духовності української нації, не торкнувшись політичних, економічних та ін. процесів, які відбуваються в суспільстві. Тому, коли в релігієзнавстві розглядають функції релігії, одночасно помічають, що кожна 3 них перебуває у своїй протилежності, дихотомічній парі. Релігія несе в собі як інтегрувальні, так і дезінтегрувальні, як легітимувальні, так і дезлегітимувальні функції. У цьому розумінні історія показує, що коли суспільство звертає увагу тільки на один бік явищ, то в підсумку отримує діалектично протилежний.

Слід звернути увагу, що розвиток світових релігій у минулому супроводжувався пропозицією більш досконалої форми організації суспільства. 3 одного боку, вони сприяли розвитку національної ідентичності (кожна світова релігія трансформувалася: звідси, можна сказати, скільки існує держав, у яких вони поширені, стільки й існує їхніх різновидів); із другого боку, наднаціональний характер цих релігій сприяв виникненню нових форм організації й управління 
суспільством, виникненню територіальних імперій. I тому, коли ми говоримо про методологічні можливості православ'я як світової релігії, то ми не можемо відірвати iіi від неї самої ж, від тієї соціально-правової форми, яка вона несе в собі. Час імперій територіальних давно вже змінився новими «видами імперій» - ідеологічними, інформаційними й т.д. Як неможливо ввійти в одну й ту ж річку двічі, так i неможливо повноцінно інтегрувати будь-яку історичну релігію в правове поле сучасної України, не зруйнувавши іiі ж державності. Будь-яка релігія в цьому розумінні всередині себе містить внутрішній соціально-правовий конфлікт. I, залучаючи будь-яку 3 них для побудови української державності, ми «підливаємо масла у вогонь» (пробуджуємо внутрішній конфлікт і надаємо йому нового звучання в сучасних умовах). У цьому розумінні, на думку Ю. В. Тіхонравова, такий союз між релігією й правом здатний призвести до двох форм його виродження - або «поліцейської релігії», або «релігійної поліції» [7, с. 61-66].

Багато дослідників зауважують, що реалізація ідеї об'єднання християнських церков України в умовах плюралізму релігійного життя й утворення об'єднаної національної церкви на підставі визнання винятковості однієї 3 конфесій i згуртування навколо неї інших християнських течій зараз практично й теоретично неможлива. Це об’єднання на певних паритетних засадах не може статися з багатьох причин: 1) жодна $з$ християнських конфесій в Україні не є вихідною; 2) час існування кожної з християнських конфесій зовсім не збігається з часом існування християнства в Україні; 3) поява тієї чи іншої християнської конфесії - відображення об'єктивного процесу історичного розвитку й виникнення їі можливо тільки на підставі такого ж процесу; 4) сприйняття себе послідовниками кожної конфесії як єдино істинної релігії формує міжконфесійну упередженість, виключаючи можливість взаємного переходу; 5) непоступливість у визначенні ідентичності ідеї вселенського християнства, яке прийняв Володимир Великий, цьому перешкоджає у визначенні шляхів зближення християнських конфесій; 8) небажання керівництва християнських конфесій в Україні втратити свої позиції і свій керівний статус в організаційній структурі й відповідні привілеї та почесті [3, с. 695-696].

Щодо цього треба розуміти, що жодна $з$ наявних церков не може претендувати на статус єдиної церкви в Україні. Утворення такої церкви, якщо реально оцінювати ситуацію, стане можливим лише тоді, коли відбудуться колосальні трансформації у всіх сферах життя сучасного суспільства. Причому цілісне розуміння цих питань можливе тільки за методологічного прориву розуміння релігії взагалі, коли ми в ній будемо бачити не інструмент реалізації власних амбіцій держави, а цілісний соціальний організм, що втілюється й у різних формах життя суспільства.

Проте не все так погано. Виникнення коопераційної моделі церкви й держави в Україні стало можливим завдяки діяльності «академічного релігієзнавства». Нова виникла модель може в подальшому призвести до делегування деяких функцій держави власне релігії, а далі до переходу від «поліцейської релігії» до виникнення й формування більш тісних взаємин у релігійній сфері, для природного ії контролю. I, можливо, до зникнення необхідності в експертній діяльності щодо НРР. На наш погляд, для реалізації такого завдання повинні існувати вертикаль принципів, 
задавана градусом наукових досліджень у державі, і зміна правових законів, що регулюють діяльність релігій у державі. Сдине, що головний підсумок подібних ініціатив повинен бути такий, щоб результат діяльність таких традицій не був зведений до повторення історичної онторелігіогенези, яка вже склалася 3 досвіду реалізації відпрацьованих технологій роботи у взаємодії з державою, або нових, наприклад, контроль і підтримання релігійного тероризму, різних гібридних викликів на релігійному грунті, повернення до монархії. Так, сучасне зростання тероризму показує, що з будь-якої релігії можна зробити інструмент для вбивства. Тому різкий підйом зараз православного екстремізму, спровокований на підставі того ж підходу i тих ж методів, якими були розхитані мусульманські екстремісти в минулому й сучасному світі, несе в собі також багато загроз для нашого суспільства.

Таким чином, на розгляд виносяться наступні висновки. Проблема релігієзнавчої експертизи НРР є комплексною й залежить від подальшого її вирішення мінімум у трьох сферах.

В історико-онтологічному ракурсі необхідно переглянути й розвинути базові поняття, на яких грунтується сучасне релігієзнавство. Вихід із теоретичного рівня на практичний, від аналізу понять до проблеми й можливостей релігієзнавчої експертизи, убачається також у необхідності розкриття проблеми контролю в релігійній сфері в історії. Зв'язок між теоретичним і історичним - це перший аспект проблеми релігієзнавчої експертизи НРР.

У гносеологічно-методологічному ракурсі зовнішній характер усіх методологічних позицій, які досліджують сучасне релігійне життя, указує лише на розрив, що виникає в розумінні релігієзнавчої експертизи. Відсутність взаємозв'язку між iї передумовами й результатом, якого прагнуть дослідники, указує на штучність проблеми й нав'язаний характер цієї процедури для суспільства. Однак негативний досвід ії використання не повинен призвести до відмови від неї. Він тільки свідчить, що проблема може бути вирішеною в іншій сфері - феноменологічному ракурсі.

У цій сфері «природний» контроль релігійного життя, у тому числі й НРР, стане можливим тільки в разі створення нової моделі організації суспільства. Поява концепцій соціального партнерства держави й релігійних організацій, ідей створення національної церкви говорить про початок цієї трансформації. На наш погляд, це може стати побудовою держави нового типу. Це за своєю сутністю еволюція релігії, де сфера, можливо, ідеології, релігійної за своєю формою, власне фактом свого існування зможе контролювати процеси, що відбуваються в суспільстві.

\section{Література:}

1. Дворкин А. Введение в сектоведение : учебн. пособ. к курсу «Сектоведение». Н. Новгород, 1998. 457 с.; Дворкин A. Сектоведение. Тоталитарные секты. Опыт систематического исследования. Н. Новгород, 2007. 813 с.; Чернышеев В. М. Сектоведение. Киев, 2006; Конь Р. М. Введение в сектоведение. Н. Новгород, 2008. 496 с.; Мартинович B. A. Нетрадиционная религиозность: возникновение и миграция. Материалы к изучению нетрадиционной религиозности. Т.1. Минск, 2015. $560 \mathrm{c}$. 
2. Загребина И. В. Государственная религиоведческая экспертиза. Теория и практика. М., 2012. 224 с.; Религиозные объединения. Свобода совести и вероисповедания. Нормативные акты, судебная практика, заключения экспертов. М., 2012. 1456 с.; Загребина И., Пчелиниев А. В. Религиоведческая експертиза: учебн. М., 2016. 450 с. $735 \mathrm{c}$.

3. Історія релігії в Україні : навч. посіб. / А. М. Колодний, П. Л. Яроцький та ін. Київ, 1999.

4. Качурова С. В. Судьба последних религиозных новаций. Харьков, 2007. 210 с.

5. Социальное партнерство государства и религиозных организаций : монограф. М., 2009. 232 с.

6. Старков О. В., Башкатов Л. Д. Криминотеология: религиозная преступность / под общ. ред. О. В. Старкова. СПб., 2004. 386 с.

7. Тихонравов Ю. В. Судебное религиоведение. М., 1988. 272 с.

8. Тонконогов A. B. Пенитенциарная сектология: учебно-практическое пособие. М., 2004. $121 \mathrm{c}$.

9. Хвыля-Олиентер А. И. Пособие для православных миссионеров по сравнительному богословию и сектоведению. М., 2001.

\section{References:}

1. Dvorkin A. Vvedenie $v$ sektovedenie [Introduction to sectology]. Uchebnoe posobie $k$ kursu «Sektovedenie». N. Novgorod, 1998. 457 s.; Dvorkin A. Sektovedenie. Totalitarnyie sektyi. Opyit sistematicheskogo issledovaniya [Sect Studies. Totalitarian sects. Systematic research experience]. N. Novgorod, 2007. 813 s.; Chernyishev V. M. Sektovedenie [Sect studies]. Kiev, 2006.; Kon R M. Vvedenie v sektovedenie [Introduction to sectology]. N. Novgorod, 2008. 496s.; Martinovich V. A. Netraditsionnaya religioznost: vozniknovenie $i$ migratsiya. Materialyi $k$ izucheniyu netraditsionnoy religioznosti [Nontraditional religiosity: the emergence and migration. Materials to the study of non-traditional religiosity]. T1.Minsk, 2015. 560 s.

2. Zagrebina I. V. Gosudarstvennaya religiovedcheskaya ekspertiza. Teoriya i praktika [State religious expertise. Theory and practice]. M., 2012. 224 s.; Religioznyie ob'edineniya. Svoboda sovesti $i$ veroispovedaniya. Normativnyie aktyi, sudebnaya praktika, zaklyucheniya ekspertov [Religious associations. Freedom of conscience and religion. Regulations, court practice, expert opinions]. M., 2012. 1456 s.; Religiovedcheskaya ekspertiza: uchebnik dlya bokalavrata $i$ magistraturyi [Religious examination: $a$ textbook for bokalavrata and magistracy] / I. Zagrebina, A. V. Pchelintsev M., 2016. 450 p.

3. Istoriya religiyi v Ukrayini: Navchalniy posIbnik [History of Religion in Ukraine: Textbook] / A. M. Kolodniy, P. L. Yarotskiy ta In. K., 1999. 735 p.

4. Kachurova S.V. Sudba poslednih religioznyih novatsiy [The fate of the latest religious innovations]. H., 2007. 210 p.

5. Sotsialnoe partnerstvo gosudarstva $i$ religioznyih organizatsiy [Social partnership of the state and religious organizations]. Monografiya. M., 2009. 232 p.

6. Starkov O. V., Bashkatov L.D. Kriminoteologiya: religioznaya prestupnost [Criminotheology: religious crime]/ Pod obsch. Red. O.V. Starkova. SPb., 2004. 386 p.

7. Tihonravov Yu. V. Sudebnoe religiovedenie [Judicial Religion]. M., 1988. 272 p.

8. Tonkonogov A. V. Penitentsiarnaya sektalogiya: uchebno-prakticheskoe posobie [Penitentiary sectalogy: educational and practical manual]. M., 2004. 121 p.

9. Hvyilya-Olienter A. I. Posobie dlya pravoslavnyih missionerov po sravnitelnomu bogosloviyu $i$ sektovedeniyu [Handbook for Orthodox missionaries in comparative theology and sectology]. M., 2001. 


\section{Vitaliy Soloviev}

\section{RELIGIOUS EXAMINATION OF NEW RELIGIOUS MOVEMENTS: MAIN ANGLES}

The article deals with the problem of religious scholarly examination of new religious movements. Unfortunately, the topic of religious scholarly examination has not found theoretical understanding, and to this day remains beyond the scope of scientific research. The first attempt to comprehend the problems here is the monograph by Yu.V. Tikhonravov «Judicial Religion», published in 1998, where for the first time methodological questions were set concerning the possibility of «using special religious knowledge for procedural purposes». He drew attention to the controversy of the possible application of this procedure in the legal field, highlighting the ethical and ideological, methodical and methodological, organizational and legal issues of religious scholar examination. However, the need for more in-depth study of data issues forced the researchers to seek a methodological form that could adequately reflect the problem of the realization of religious scholarship expertise.

Not enough investigation of such important issues as nature, features and functions of religious examination, conditions and special methods of its realization, the subject and the object of expertise, the status of an expert and ethical problems during the religious scholarly expertise, limits of using special knowledge force to address to the need for methodological analysis of this concept. In addition, the penetration of legal terminology and procedures into religious studies raised the question of the admissibility of a formal transfer, which may lead to incorrect assumptions and distortions in the perception of religions themselves. In general, if we take a look at the religious scholarly examination, we may notice that the methodology of this procedure is a general scientific task of defining, classifying and evaluating any subject of the study. And the problem itself arises when the law, penetrating ino the field of religious studies, attempts to formalize religion and to erode its content and involuntarily destroys its understanding.

It is also possible to notice that this present-day problem is connected with the concept of «secular state», because the expertise in religious affairs in history, as the Inquisition in the Catholic Church or the spiritual examination on the basis of sectology in the Russian Orthodox Church, occurs at a time when modifications of the models of relations between the church and the state are taking place. By the way, the bursts of the emergence of the NRF in one or another state are connected with the changes in the legislative sphere in religion. To sum up, one can safely assert that, on the one hand, the essence of the NRF is covered in matters of relations between the church and the state. On the other hand, the necessity for the examination of NRP arises when this dichotomous system is joined by different dictatorial systems, which are trying to eliminate this contradiction. Therefore, the problem of examination of NRF can be considered from three perspectives. ideology.

Keywords: religious expertise, new religious movements, secular state, church, 


\section{Вімалій Соловйов}

\section{РЕЛІГІСЗНАВЧА ЕКСПЕРТИЗА НОВИХ РЕЛІГІЙНИХ РУХІВ: ОСНОВНІ РАКУРСИ}

У статті розглянуто проблему релігієзнавчої експертизи нових релігійних рухів. На жаль, тема релігієзнавчої експертизи практично не знайшла теоретичного осмислення й до сьогодні залишається за межами наукових досліджень. Першою спробою осмислення цих проблем $є$ монографія Ю.В. Тихонравова «Судове релігієзнавство», що вийшла в 1998 р. і вперше поставила методологічні питання про можливість «застосування спеціальних релігієзнавчих знань в процесуальних цілях». Він звернув увагу на суперечливість можливого застосування цієї процедури в правовій сфері, виділяючи етичні й ідеологічні, методичні й методологічні, організаційно-правові проблеми релігієзнавчої експертизи. Однак необхідність більш поглибленого дослідження цих питань змушувала дослідників шукати методологічну форму, яка могла б адекватно відтворювати проблему реалізації релігієзнавчої експертизи.

Недослідженість таких важливих питань, як природа, ознаки й функції релігієзнавчої експертизи, умови й спеціальні методи ії проведення, предмет і об'єкт експертизи, статус експерта й етичні проблеми під час проведення релігієзнавчої експертизи, межі застосування спеціальних знань, змушують звернутися до необхідності методологічного аналізу даного поняття. Крім того, проникнення юридичної термінології й процедур до релігієзнавства поставило питання про допустимість формального перенесення, яке може призвести до неправильних припущень і спотворень у сприйнятті самих релігій. Узагалі, якщо придивитися до релігієзнавчої експертизи, то ми можемо помітити, що методично за цією процедурою стоять загальнонаукові завдання визначення, класифікації й оцінки будьякого предмета дослідження. I сама проблема виникає, коли право, вторгаючись у галузь релігієзнавства, намагаючись формалізувати релігію, вихолощує іiі зміст і несвідомо саме руйнує іiі розуміння.

Так само можна помітити, що ця проблема в сучасності пов'язана 3 поняттям «світська держава», тому що експертиза в справах релігії в історії, як інквізиція в католицькій церкві або духовна експертиза на основі сектознавства в російській православній церкві, виникає в той момент, коли відбувається видозміна моделей відносин між церквою й державою. До речі, власне сплески появи НРР у тій чи іншій державі пов'язані саме зі змінами в законодавчій сфері в релігії. Тому можна сміливо стверджувати, що, з одного боку, сутність НРР ховається в питаннях відносин між церквою й державою. Із другого боку, необхідність в експертизі НРР виникає, коли до цієї дихотомічної системи залучаються різні гносеологічні концепції, які намагаються зняти цю суперечність. Тому проблема експертизи НРР, на наш погляд, може бути розглянута в трьох ракурсах.

Ключові слова: релігієзнавча експертиза, нові релігійні рухи, світська держава, церква, ідеологія. 
Soloviev Vitaliy - Assistant Professor of the Department of Philosophy of the National Aerospace University «Kharkiv Aviation Institute».

Соловйов Віталій - асистент кафедри філософії гуманітарного факультету Національного аерокосмічного університету ім. М.С. Жуковского «Харківський авіаційний інститут».

...Мое знайомство з викладачами кафедри філософії й самим предметом філософії було подібним до відомого афоризму Арістотеля: «Подив спонукає людей філософствувати». Саме таке спочатку неясне переживання відбилося в молодій студентській душі, мої майбутні колеги: Магомедов К.М., Рязанцева Л.В. були лекторами, Качуров Е.В і Карогодова Є.П. проводили семінарські заняттяя. Особливий стиль, деяка харизма супроводжували зародження уваги й інтересу до предмета.

Час мого навчання в університеті супроводжувався кризовими явищами, що охопили різні боки суспільного життя. Інтерес до духовного життя суспільства, що характеризусться сплеском нової релігійності, появою різних сект і культів підштовхнув до пошуків у цій сфері. Можливість спостерігати своїми очима злети й падіння лідерів нових релігійних рухів породжувала безліч питань, пошуки відповідей на які привели до аспірантури. Тут кожен викладач залишив свій слід, допомагаючи розкрити різноманіття граней філософського знання. «Усе подальше життя буде пов'язаним із вивченням філософії», - зауважив К.А. Байрачний, очінюючи кандидатський іспит на оиінку «добре» $i$ тим самим мотивуючи процес необхідності постійного вдосконалення свойх навичок і вмінь y подальшому. Як мій науковий керівник, він назавжди визначив вектор моїх наукових інтересів. Можливість суміщення особистих духовних пошуків і професійної кар'єри на кафедрі стала діалектикою мого власного розвитку. «Повалення помилкових чужих богів», «нездатність задовольнитися ніяким ззовні даним змістом життя» $i$ в той же час твердження нових смислів - ией подвійний прочес, руйнівний і одночасно творчий, є шляхом для мене на кафедрі філософії. Досвід філософії, який дозволяє кожній людині бути людиною.

Соловйов Віталій Георгійович - асистент кафедри філософії. Після закінчення аспірантури працює на кафедрі двадцять років.

Надійшла до редакції 04.03.2019. Розглянута на редколегії 18.03.2019.

\section{Рецензенти:}

Доктор філософських наук, професор кафедри філософії Наџіонального аерокосмічного університету ім. М.С. Жуковського «ХАІ» Кузнещов А.Ю.

Кандидат філософських наук, дочент, завідувач кафедри права Національного аерокосмічного університету ім. М.С. Жуковського «ХАІ» Селевко В.Б. 